\title{
Eppley Cancer Center
}

National Cancer Institute

\section{Source}

National Cancer Institute. Eppley Cancer Center. NCI Thesaurus. Code C39553.

The mission of the Eppley Cancer Center is to coordinate basic and clinical cancer research, patient care, and educational programs, and to facilitate the application of new knowledge about the etiology, diagnosis, treatment, and prevention of cancer. The Center incorporates the expertise and resources from the colleges and institutes at the University of Nebraska Medical Center as well as its affiliated hospital, The Nebraska Medical Center. It became an NCl-designated cancer center in 1999. 